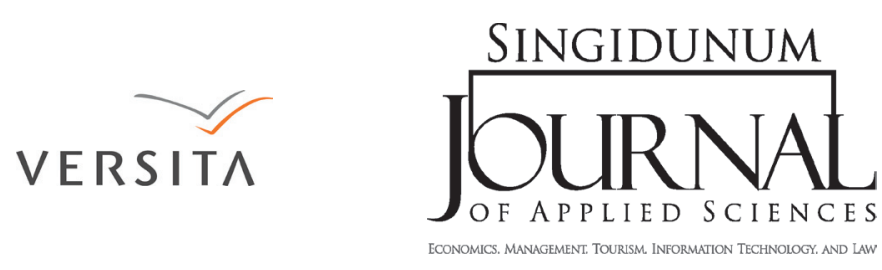

SINGIDUNUM JOURNAL 2013, 10 (2): 24-31

ISSN 2217-8090

UDK 005.51/.52:640.412

DOI: $10.5937 /$ sjas $10-4481$

Review paper/Pregledni naučni rad

\title{
THE PERFORMANCE OF THE SERBIAN HOTEL INDUSTRY
}

\author{
Saša I. Mašić ${ }^{1, *}$ \\ ${ }^{1}$ High School of Tourism \\ Otona Župančiča 4, Belgrade, Serbia
}

\begin{abstract}
:
The aim of this paper is to determine operating performance of hotel companies in Serbia. The analysis was conducted on a sample that included approximately $31.35 \%$ of the total available hotel capacity in Serbia for the period from 2004 to 2011 . The sample was designed to be representative of the hotel distribution by territory and category. Business performance of hotel companies was analyzed using TREVPAR and GOPPAR indicators both at the national level, for tourism clusters and the largest Serbian cities. The results show that hotel companies in Serbia, on average, achieved low TREVPAR and GOPPAR values. In 2011, the average TREVPAR of companies in Serbia was 28 EUR, and GOPPAR approximately 3.7 EUR. The study registered a significant decline in the value of these indicators for the period from 2008 to 2011, primarily as a result of the economic crisis. Results significantly better than the national average were achieved by hotel companies from Belgrade that had a mean TREVPAR value of 46.2 EUR and GOPPAR value of 8.6 EUR. During the analyzed period, the largest increase in the value of the analyzed indicators was registered in the city of Kragujevac as a result of significant investments made by the car manufacturer "Fiat" and its sub-contractors. These investments have led to a significant increase in the number of foreign tourist arrivals and consequently to an increase in business performance of hotel companies in Kragujevac.
\end{abstract}

\section{Key words:}

TREVPAR, GOPPAR,

Serbia,

hotel industry.

\section{INTRODUCTION}

RevPAR (Revenue Per Available Room) is the most commonly used indicator for measuring hotel performance. It can even be said that there is arguably an industry wide obsession with RevPAR despite recognition of its well established weaknesses (Atkinson and Jones, 2008, p. 231).

It is an indicator of financial performance and represents a ratio of room revenue and the total number of available rooms.
Equation 1: Revenue per available room (RevPAR) ratio formula

REVPAR = Average daily room rate $(\mathrm{ADR}) *$ Occupancy $(\%)$ or

$$
\text { REVPAR }=\frac{\text { Total room revenue }}{\text { Number of rooms } \times 365}
$$

TREVPAR (Total Revenue Per Available Room) is an indicator of business success and represents a ratio of total operating revenues and the total number of available rooms. 
Equation 2: Total revenue per available room (TREVPAR) ratio formula

$$
\text { TREVPAR }=\frac{\text { Total turnover }}{\text { Number of rooms } \times 365}
$$

TREVPAR is a more comprehensive indicator than RevPAR as it takes into account not only the room revenue but also other revenues generated by a hotel. However, it may be an inappropriate measure when benchmarking one hotel against another as it includes total hotel revenue. Hotels located near major tourist destinations are likely to have more diverse contents and higher shares of other revenues (Čačić, 2010), and thus, this indicator will underestimate the hotels whose primary source of revenue is accommodation and that are less dependent on other income generating operations (Lindt, 2006).

GOPPAR (Gross Operating Profit Per Available Room) is an indicator of total operating profit, i.e. the difference between operating income and controllable operating expenses:

Equation 3: Gross operating profit per available room (GOPPAR) ratio formula

$$
\text { GOPPAR }=\frac{\text { Gross operating profit }}{\text { Number of rooms } \times 365}
$$

According to Hayes (Hayes and Miller, 2011), GOPPAR is as popular with the managers as it is with the hotel owners because:

- all hotel and not just room revenue is measured,

- GOPPAR also takes into account operating expenses that may be influenced by company management and for which it may be held accountable.

Unlike RevPAR and TREVPAR that consider only business income, the value of GOPPAR is influenced by the ability of managers to generate business income, and their ability to control the level of operating expenses (Pizam, 2005). Therefore, RevPAR should not exclusively be used to measure the success of management performance (Dopson and Hayes, 2009). According to Harris and Mongiello (2006, p. 100), GOPPAR reflects the operating profit potential of a hotel, thus giving a better indication of the overall performance.

\section{RESEARCH METHODOLOGY}

The performance of hotel companies in Serbia was calculated and analyzed on a defined sample of 56 hotel companies that operate 73 hotels with approximately 6,260 hotel rooms or $31.35 \%$ of the total hotel capacities in Serbia.

Representative sample calculation was made by taking into account the need for a sufficiently large sample size as well as the adequate representation of hotels by category and location in Serbia. However, several problems were encountered during sampling. The most significant was that a large number of hotels in Serbia operate as part of complex enterprises engaged in the activities outside the hotel industry. It was not possible to identify data relating only to hotel operations on the basis of the company's financial records, and thus, these hotels could not be included in the sample. At the same time, the sample could only include companies that were continuously in business throughout study period as determined by the Serbian Business Registers Agency data. During this time period, a significant number of hotels was privatized and became a part of larger corporations whose consolidated financial statements did not allow the separation of hotel revenue. Therefore, these hotel companies were excluded from the sample despite their eligibility as continuously operating enterprises.

For the purpose of calculating the hotel business performance indicators, financial statements and solvency data from the Serbian Business Registers Agency were used. It is necessary to mention that the method of presenting data in balance sheets in Serbia differs from that of other countries that routinely use the above-given indicators to quantify hotel operating performance. In other words, values needed to calculate RevPAR are not obvious from the financial data provided to the Serbian Business Registers Agency. As previously mentioned, although it is possible to determine the company's total operating revenue, it is not possible to separately identify room revenue, thus preventing a precise calculation of RevPAR. However, since several companies did report this in annexes to their financial statements, and for some this information was collected through interviewing company management, it was possible to estimate the value of this indicator.

TREVPAR and GOPPAR values were calculated based on the comprehensive hotel financial data and were reported for the complete sample. Gross 
Operating Profit (GOP) required for GOPPAR was calculated as a difference between total operating revenue and controllable operating expenses. It is important to note that in accordance with the international accounting standards, GOP calculation did not include financial and other income and expenditures. Calculation of TREVPAR and GOPPAR values was performed for the entire sample, tourism clusters as well as for all major cities.

Tourism improvement is considered to be one of Serbia's development priorities. The country adopted the Tourism Development Strategy which aims to "achieve the increased competitiveness of Serbian tourism, increase foreign exchange earnings, domestic tourist traffic, as well as job growth through tourism, in order to transform the Republic of Serbia into a competitive tourism destination". It identifies Vojvodina, Belgrade, Western Serbia and Eastern Serbia as four major tourism clusters (Službeni glasnik Republike Srbije, 2006).

The average value of TREVPAR and GOPPAR was calculated for the hotel companies included in the sample and classified by cluster. Amounts were originally calculated in Serbian RSD and were later on converted into EUR using the average exchange rate on the last working day for each year covered in the analysis.

\section{RESULTS AND ANALYSIS}

The calculation and analysis was conducted for TREVPAR and GOPPAR indicators for the period 2004 - 2011. (Figure 1).
Two distinct periods can be identified based on TREVPAR values. The first period is from 2004 to 2007 during which an increase in the value of TREVPAR was registered, followed by a subsequent decline from 2008 to 2010 and a slight recovery in 2011. A similar increasing trend could be observed with GOPPAR until 2007, followed by a trend of continuous decline. Since these values are denominated in EUR, the decline is also partially influenced by the depreciation of RSD, particularly during the period from 2008 to 2011. Even when analyzing TREVPAR expressed in RSD, there was an obvious decline in these values from 2009 to 2010, and a subsequent moderate recovery in 2011. This corresponds to the period of significant economic downturn which was probably the main cause of the observed TREVPAR decline. The economic crisis led to the business volume reduction, as well as the reduction of the volume of foreign direct investment and other foreign exchange inflows including the supply of foreign currency and the resulting exchange rate depreciation. However, the overall decline in the value of these parameters can not be attributed solely to external factors, but also to the discrepancy between the inability of hotels to respond to modern market demands, both in terms of quality, and, in some regions quantity.

As the calculation of TREVPAR does not include spending needed to generate revenue, GOP$\mathrm{PAR}$ is a better indicator of the company's earning capacity.

When we look at the GOPPAR values, it is clear that hotel companies during the study period, on

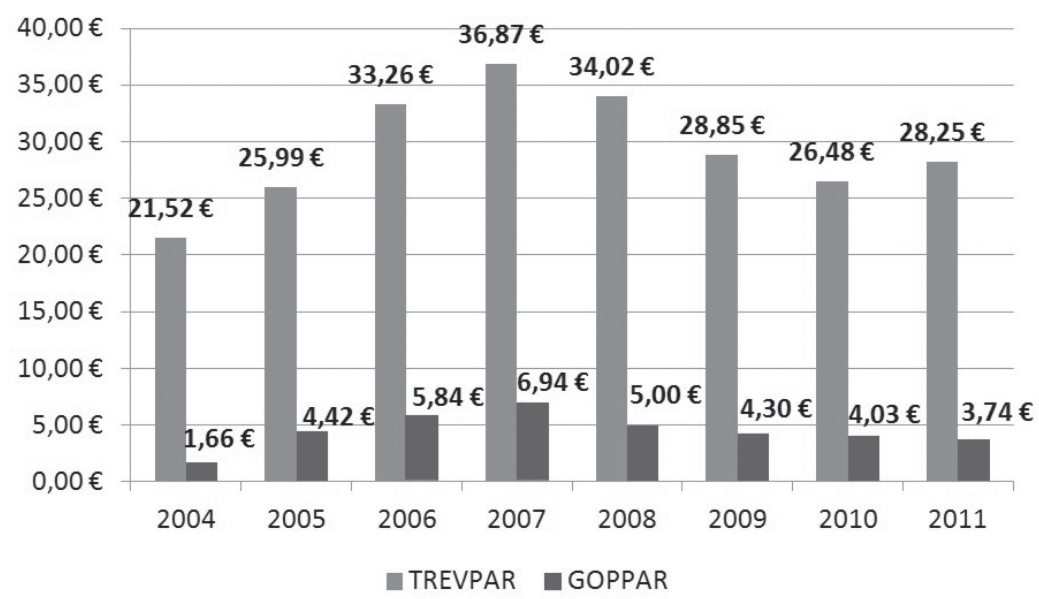

Figure 1: TREVPAR and GOPPAR of hotel companies in Serbia for the entire sample during the period 2004 - 2011. 
average, achieved very modest results. However, we need to take into consideration that when calculating GOPPAR, both depreciation costs and interests must be financed through GOP. The average value of 3.74 EUR per day per room was often not sufficient to cover these expenditures as demonstrated by the fact that during this period a large number of enterprises registered a total net loss.

The results of hotel companies differ significantly for the tourism clusters in Serbia (Figure 2). As expected, the best results were achieved by Belgrade hotel companies.

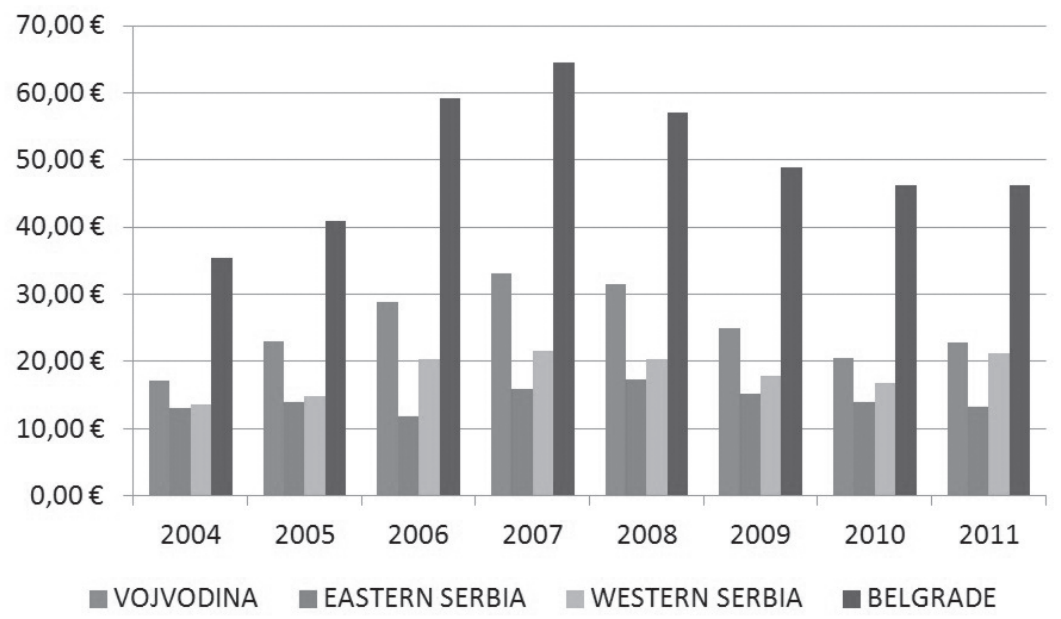

Figure 2: TREVPAR of hotels from different tourism clusters from 2004 to 2011.

During this study period, the highest TREVPAR growth was registered in the "Western Serbia" cluster. However, if we look at the TREVPAR values for the entire analyzed period, even the lowest registered average TREVPAR value in Belgrade was higher than any best result achieved by hotel companies in any other cluster and at any given time period. In the last year of analysis, the average TREVPAR value of the hotel companies in "Belgrade" cluster was about 2 times greater than the average value registered in the cluster "Vojvodina", 2.18 times greater than the value in the "Western Serbia" cluster and about 3.5 times greater than the value in the cluster "Eastern Serbia."

Values calculated for Belgrade hotel companies are, to a large extent, a result of their favourable location. In 2010, Serbia recorded a total of $1,452,156$ overnight stays of foreign tourists, of which 809,822 in Belgrade (Statistical Office of the Republic of Serbia, 2011). The majority of those visits were business related, making Belgrade (a business and administrative center of Serbia) a preferred destination. Contrary to this, the distribution of overnight stays of domestic tourists shows less of a tendency towards concentration. In 2010, Belgrade's share in the total number of domestic overnight tourist stays was only 10.28\% (Statistical Office of the Republic of Serbia, 2011). These data demonstrate that foreign travellers primarily contributed to the results achieved by Belgrade hotel companies.

Although there are differences in the levels of measured TREVPAR, there are considerable similarities in trends during the study period. Hotel companies in all clusters except "Eastern Serbia" registered an increase in TREVPAR values from 2004 to 2007, followed by a fall and later on a slight recovery in 2011. Hotel companies in the cluster "Eastern Serbia" recorded the lowest TREVPAR values in 2006, followed by a brief recovery until 2008, after which there was again a drop in values.

Since TREVPAR does not take into account costs incurred in order to achieve revenue, it is important to include both controllable operating expenses as well as to determine how they reacted to changes in the registered business income when determining the GOPPAR value. 


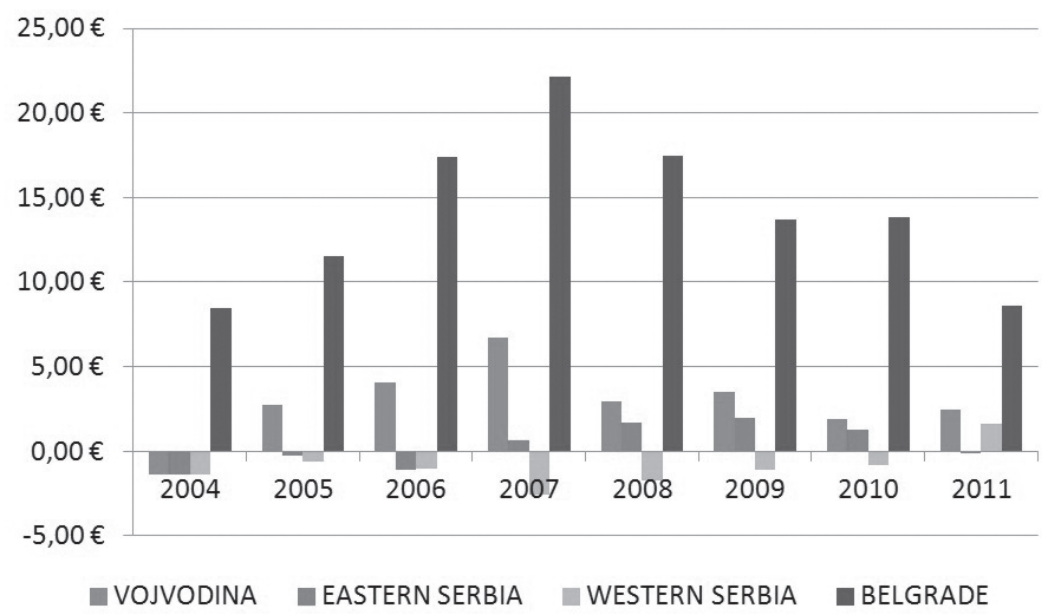

Figure 3: GOPPAR of hotels from different tourism clusters in the period 2004-2011.

Based on the data presented in the graph (Figure 3), it can be observed that the best results measured by GOPPAR were achieved by companies from Belgrade. It is important to note that hotel companies from the "Western Serbia" cluster on average registered positive GOPPAR values for the first time in 2011. A positive trend in their business can be observed despite difficult economic conditions caused by the economic crisis.

It is also important to analyze and compare achieved GOPPAR values of companies from different clusters. GOPPAR of companies from the Belgrade cluster is 3.5 times greater than the one registered in the "Vojvodina" cluster, and about 5.4 times greater than those in the "Western Serbia" cluster. By observing TREVPAR values ranging between 2 and 3.5 it is clear that hotel companies from the Belgrade cluster were, relatively speaking, able to achieve the same revenue with lower controllable operating expenses. Although more favourable supply conditions in all Belgrade markets can partially explain these differences, better cost control is also likely to be the result of management performance.

Registered GOPPAR values, particularly in the companies outside Belgrade cluster, do not give reason for much optimism. GOPPAR values during the analyzed period show that companies are unlikely to finance any significant investments from operating revenues, and that they will probably need to rely on external capital source in order to be able to respond to modern market requirements.

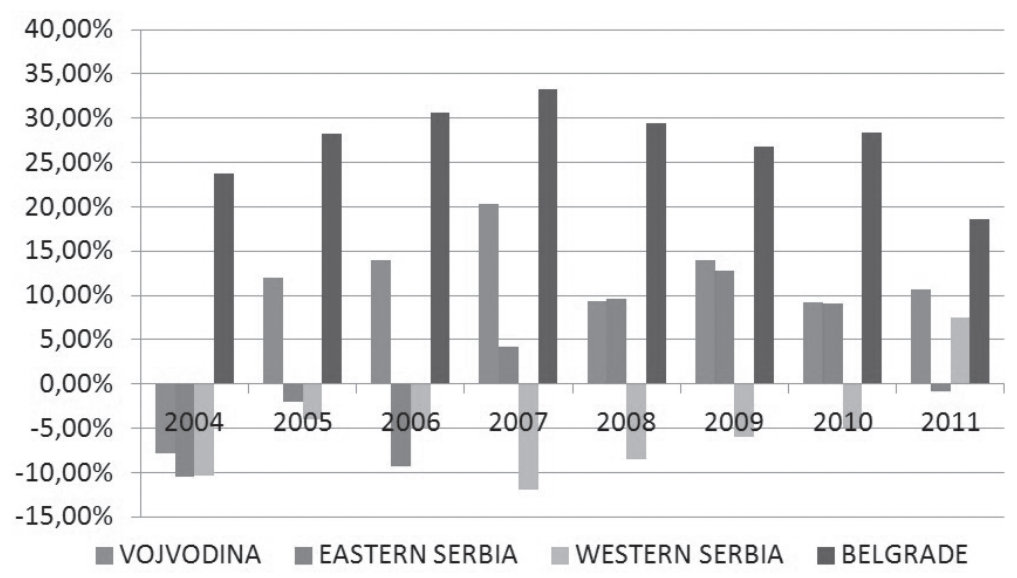

Figure 4: GOP margin in tourism clusters from 2004 to 2010. 
Based on the presented data (Figure 4), it can be concluded that the highest GOP margin was recorded within the Belgrade cluster, but with a notable reduction in 2011 compared to previous years. In 2011, of every 100 RSD of generated operating income within Belgrade cluster, 18.62 RSD was GOP.
TREVPAR and GOPPAR values were calculated for the hotel companies located in major Serbian cities: Belgrade, Novi Sad, Niš and Kragujevac.

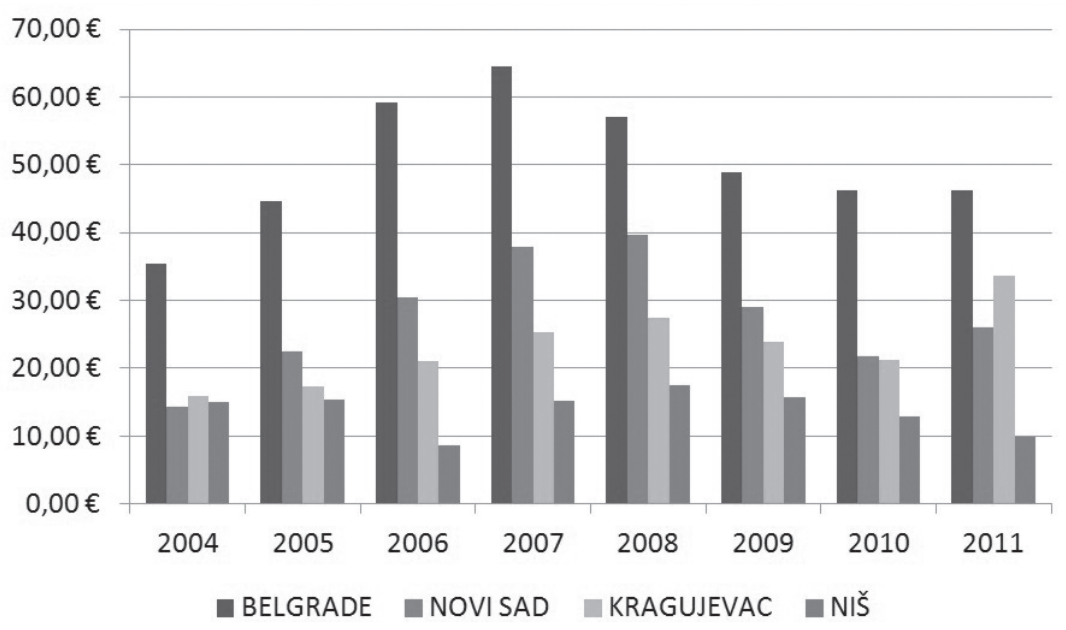

Figure 5: TREVPAR of hotels in Belgrade, Novi Sad, Kragujevac and Niš from 2004 to 2011.

As can be observed in the given graph, it is evident that the hotel companies from Belgrade achieved significantly better results than hotel companies in Novi Sad, Kragujevac and Niš (Figure 5). The largest increase in TREVPAR was registered in Kragujevac owing to the large investments made by "Fiat" and its sub-contractors. The opening of new car production facilities has led to the sharp increase in the number of foreign visitors to Kragujevac, as well as the total number of registered overnight stays. According to the 2007 data from the Statistical Office and the Tourist Organization of Kragujevac, the city registered 20,373 tourist arrivals and 45,103 overnight stays. The share of foreign tourists in the total number of tourist arrivals was about $37 \%$, and around $36 \%$ in the number of overnight stays. In 2011, Kragujevac registered a total of 30,673 tourist arrivals and 84,647 overnight stays. Out of the total number of tourists, foreign tourists accounted for about $45 \%$ and $53 \%$ of the total number of overnight stays. In the last 5 years of the analysis, Kragujevac had a $51 \%$ increase in the number of tourist arrivals and $88 \%$ in the number of overnight stays. This increase was particularly important in the area of foreign tourist arrivals (84\%) and the number of their overnight stays (146\%). As anticipated, most of the foreign tourists were from Italy. Bearing in mind that during this period the capacity of hotel facilities in Kragujevac remained unchanged, it is evident that the increase in the number of tourists had a considerable impact on the registered increase in TREVPAR and GOPPAR.

As already pointed out, TREVPAR takes into account complete operating revenue including the room revenue and other operating income. Unlike TREVPAR, RevPAR includes only room revenues in its calculation.

It is usually not possible to identify the room revenue in Serbia on the basis of the accounting information presented in hotel income statements or the accompanying notes. In the study sample, this information was reported only by several hotels in their financial statements, while for some it was collected through a management survey. Even though the collected information was not sufficient to make general conclusions, it is possible to make certain assumptions. For the given study period, the share of room revenues in the total operating revenues of hotels in Belgrade (based on the available data) ranged between $65-70 \%$, with a tendency towards a gradual increase. This share is slightly lower in Niš and Kragujevac at about 50\%. If these indicators of room revenues were applied to the determined TREVPAR values, it would be possible to get a rough estimate of RevPAR in these cities. 
Having in mind that the Belgrade cluster had an average registered TREVPAR of 46.21 EUR in 2011 , and that a rough estimate of room revenue was about $70 \%$, the expected value of RevPAR can be calculated to 32 EUR. Similarly, the estimated RevPAR values for Kragujevac and Niš cluster for the same year were 17 EUR and 5 EUR respectively.

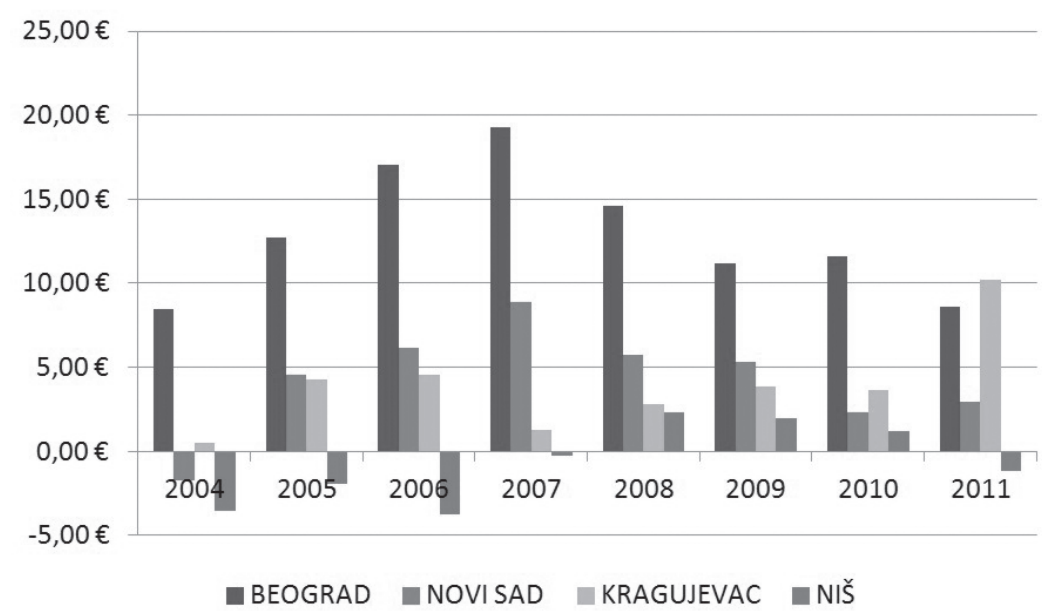

Figure 6: GOPPAR of hotels in Belgrade, Novi Sad, Kragujevac and Niš from 2004 to 2011.

By analyzing the achieved GOPPAR values at the end of 2011, it can be concluded that hotel companies in Kragujevac achieved highest values which were comparable to average GOPPAR values recorded in Belgrade (Figure 6). The fact that Kragujevac does not have a large hotel capacity, and the disparities between the recorded TREVPAR and GOPPAR values in Belgrade and Kragujevac (higher TREVPAR in Belgrade vs. higher GOPPAR in Kragujevac), speak in favour of the fact that hotel companies in Kragujevac had lower operating costs, primarily lower labour costs, compared to those in Belgrade.

Therefore, the announcement that the construction of the first branded hotel will begin shortly was not surprising, taking into account the results achieved in the hospitality market as well as the plans of new Fiat's subcontractors to start production in the region.

\section{CONCLUSION}

Based on the calculated average TREVPAR and GOPPAR values, it can be concluded that the hotel companies in Serbia achieved suboptimal business results. The average TREVPAR of hotel companies in Serbia in 2011 was 28 EUR, and GOPPAR 3.7 EUR. The fact that additional operating costs and interests not included in GOP calculations are financed through GOP indicates that the registered
TREVPAR and GOPPAR values do not provide sufficient capital required to finance investments needed for continuous adapting to modern market demands. Of particular concern is the fact that a continuing decline of GOPPAR has been observed since 2008. It is evident that the current financial crisis has greatly affected the performance of the hotel sector, but it is not the only reason for such poor results. Other factors, such as the quality of provided hotel products and the ability to comply with the needs of modern consumers, also need to be taken into consideration.

With an average TREVPAR value of 46.2 EUR and GOPPAR value of 8.6 EUR, hotel companies in Belgrade fare significantly better than those in other parts of the country. This is primarily because Belgrade is Serbia's administrative, commercial, and tourist centre, which provides hotel companies in Belgrade with a more favourable position.

Over the last few years, the greatest upward trend in performance indicators has been registered in Kragujevac, which recorded the fastest growth of TREVPAR and GOPPAR. This is primarily the result of investments made by "Fiat" and its subcontractors, which has led to a significant increase in the number of foreign tourist arrivals and overnight stays in the city. Furthermore, it has directly contributed to the improvement of the business performance of hotel companies in the city. 


\section{REFERENCES}

American Hotel \& Lodging Association., Hotel Association of New York City., \& Hospitality Financial and Technology Professionals. (2006). Uniform system of accounts for the lodging industry. Lansing, MI: American Hotel \& Lodging Educational Institute.

Atkinson, H., \& Jones, T. (2008). Financial Management in the Hospitality industry: Themes and Issues. In B. Brotherton \& R.C. Wood (Eds.), The Sage Handbook of Hospitality Management (pp. 228-257). London: Sage Publications.

Čačić, K. (2010). Poslovanje hotelskih preduzeća. Belgrade: Singidunum University. (in Serbian)

Dopson, R.L., \& Hayes, K.D. (2009). Managerial Accounting for the Hospitality Industry. Hoboken, NJ: Wiley.

Harris, P., \& Mongiello, M. (2006). Accounting and Financial Management: developments in the international hospitality industry ( $1^{\text {st }}$ ed.). London: Elsevier.
Hayes, D.K., \& Miller, A.A. (2011). Revenue management for the hospitality industry. Hoboken, NJ: Wiley.

Lindt, M. (2006). Square footage serves as more consistent benchmark option. Hotel \& Motel Management, 221(14), 14

Mašić, S. (2012). Investicioni oblici za razvoj hotelijerstva Srbije. Doctoral dissertation, Singidunum University, Belgrade, Serbia. (in Serbian)

Pizam, A. (2005). International encyclopedia of hospitality management. Boston, MA: Elsevier.

Službeni glasnik Republike Srbije. (2006). Strategija razvoja turizma Republike Srbije. Službeni glasnik Republike Srbije, 91. (in Serbian)

Statistical Office of the Republic of Serbia. (2011). Statistical Yearbook of the Republic of Serbia. Retrieved April 5, 2013, from http://www.media.srbija.gov.rs/medsrp/ dokumenti/SGS2011_cyr.pdf

\section{PERFORMANSE HOTELSKOG POSLOVANJA U SRBIJI}

\section{Rezime:}

Cilj ovog rada jeste da ispita poslovne performanse hotelskih preduzeća u Srbiji. Analiza je sprovedena na uzorku koji je obuhvatio oko 31,35\% od ukupnog broja raspoloživih hotelskih kapaciteta u Srbiji za period od 2004. do 2011. godine. Uzorak je napravljen tako da reprezentativno oslikava raspodelu hotela u Srbiji prema kategoriji i lokaciji. Poslovne performance hotelskih preduzeća ispitane su korišćenjem TREVPAR i GOPPAR indikatora na državnom nivou, u okviru turističkih klastera kao i u najvećim gradovima u Srbiji. Rezultati pokazuju da hotelska preduzeća u Srbiji, u proseku ostvaruju niske TREVPAR i GOPPAR vrednosti. Prosečna TREVPAR vrednost preduzeća u Srbiji u 2011. godini iznosila je 28 EUR, a GOPPAR oko 3,7 EUR. Ova studija zabeležila je značajan pad u vrednosti ovih pokazatelja za period 2008-2011., što je pre svega posledica ekonomske krize. Rezultate znatno iznad državnog proseka ostvarila su hotelska preduzeća iz Beograda koja su imala srednju TREVPAR vrednost 46,2 EUR i GOPPAR vrednost 8,6 EUR. Tokom perioda obuhvaćenog analizom, najveći porast u vrednosti ispitanih indikatora zabeležen je u Kragujevcu kao posledica značajnih ulaganja od strane proizvođača automobila "Fiat" i njegovih podizvođača.Ova ulaganja dovela su do znatnog porasta u broju dolazaka stranih turista, a samim tim i do povećanja poslovnih performansi hotelskih preduzeća u Kragujevcu.

\author{
Ključne reči: \\ TREVPAR, \\ GOPPAR, \\ Srbija, \\ hotelska industrija.
}

Received: September 16th,2013. Correction: September 23rd, 2013.

Accepted: September 26th, 2013. 